\title{
Pelatihan Kewirausahaan Bina Bisnis Pembuatan Pot Bunga Kekinian Untuk Masyarakat Perumahan Baruna
}

\author{
Muhammad Arif*1 Desyanti ${ }^{2}$ \\ ${ }^{1}$ Program Studi Teknik Industri, Sekolah Tinggi Teknologi (STT) Dumai \\ ${ }_{2}^{2}$ Program Studi Teknik Informatika, Sekolah Tinggi Teknologi (STT) Dumai \\ *e-mail: pakarifmt@gmail.com, desyanti734@gmailcom
}

\begin{abstract}
Based on the results of field observations and interviews with the Baruna housing community about the form of entrepreneurship they want to run during the current Covid 19 pandemic which was carried out in November 2020. There was a desire to open a contemporary flower pot business which was trending on social media at that time. Residents or residents of housing are interested in getting an explanation about how to be an entrepreneur that leads to making contemporary flower pots, thus offering the community to make entrepreneurship training and how to make these contemporary flower pots. This is important because the housing community still does not know the benefits and details of how to make flower pots, as one of the business opportunities in the future. So, an activity was made that provides information about business and the entrepreneurial spirit towards the business of selling contemporary flower pots in the residential community through a training activity and a business development workshop for making contemporary flower pots. After the activity, the community began to understand and be able to run a flower pot making business which was taught through training by having knowledge and several techniques of making flower pots as a new entrepreneurial activity.
\end{abstract}

Keywords: entrepreneurship, business development, contemporary flower pots.

\begin{abstract}
Abstrak
Berdasarkan hasil observasi lapangan dan wawancara dengan masyarakat perumahan Baruna tentang bentuk kewirausahaan yang mereka ingin jalankan selama masa pendemi Covid 19 saat ini yang dilakukan pada bulan November 2020 lalu. Diperoleh keinginan untuk membuka bisnis pot bunga kekinian yang lagi tren di media sosial saat itu. Masyarakat atau warga perumahan tertarik untuk memperoleh penjelasan tentang cara berwiraswasta yang mengarah kepada pembuatan pot bunga kekinian, sehingga menawarkan kepada masayarakat untuk membuat pelatihan kewirausahaan dan cara membuat pot bunga kekinian tersebut. Ini penting karena masyarakat perumahan masih belum mengetahui manfaat dan cara detail pembuatan pot bunga tersebut, sebagai salah satu peluang bisinis kedepannya. Maka dibuatlah kegiatan yang memberikan informasi tentang bisnis dan semangat kewirausahaan terhadap usaha penjualan pot bunga kekinian di masyarakat perumahan tersebut melalui suatu kegiatan training dan workshop bina bisnis pembuatan pot bunga kekinian. Setelah kegiatan masyarakat mulai paham dan bisa menjalankan bisnis pembuatan pot bunga yang diajarkan melaui training dengan telah memiliki ilmu dan beberapa teknik pembuatan pot bunga tersebut sebagai sebuah aktifitas kewirausasaan yang baru.
\end{abstract}

Kata kunci: kewirausahaan, bina bisnis, pot bunga kekinian

\section{PENDAHULUAN}

Perumahan Baruna adalah kompleks perumahan keluarga pegawai Kantor Navigasi Kota Dumai, yang berada di Kelurahan Bukit Datuk disamping Jalan Tega Lega Kota Dumai.Berdasarkan hasil observasi dari mitra terdapat tiga hal yang melatar belakangi kegiatan pengabdian di tempat tersebut, antara lain: pertama masyarakat atau warga perumahan tertarik untuk memperoleh penjelasan tentang cara berwiraswasta yang mengarah kepada pembuatan pot bunga kekinian, sehingga tim Pengabdian STT Dumai menawarkan kepada masayarakat untuk membuat pelatihan kewirausahaan dan cara membuat pot bunga kekinian tersebut. Kedua masyarakat perumahan masih belum mengetahui manfaat dan cara detail pembuatan 
pot bunga kekinian tersebut, sebagai salah satu peluang bisinis kedepannya. Terakhir masih terbatasnya informasi tentang bisnis dan semangat kewirausahaan terhadap usaha penjualan pot bunga kekinian di masyarakat, sehingga perlu dibuat melalui suatu kegiatan training dan workshop bina bisnis pembuatan pot bunga kekinian.

Sebagai mitra dalam pelaksanaan PPM ini adalah masyarakat di Perumahan Baruna, Kelurahan Bukit Datuk, Kecamatan Dumai Selatan. Berdasarkan maslah yang ada dapat dirumuskan dan diidentifikasikan masalah mitra sebagai berikut: pertama keterbatasan ilmu pengetahuan yang dimiliki oleh masyarakat terhadap pembuatan pot bungan kekinian yang bisa dijadikan sebagai tambahan pendapatan keluarga. Kedua masyarakat perumahan Baruna belum/tidak memiliki keterampilan khusus yang dapat memulai bisnis pot bunga kekinian. Dan, ketiga terdapat keingintahuan masyarakat tentang cara memulai wirausaha bina bisnis pembuatan pot bunga kekinian di daerah mereka.

Sedangkan tujuan pelaksanaan kegiatan PPM ini nantinya akan memberikan manfaat bagi tim STT Dumai untuk dapat menyebarkan ilmu pengetahuan tentang kegiatan memulai bisnis dengan membuat pot bunga kekinian sebagai usaha baru yang meningkatkan ekonomi keluarga. Serta bagi mitra memiliki anggota masyarakat yang memahami semangat berwirausaha dengan membuat pot bunga kekinian di rumah yang mereka miliki sebagai sebuah usaha atau bisnis keluarga. Kegiatan pembuatan pot bunga kekinian itu sendiri mulai trending di media sosial dengan adanya penawaran dari beberpapenjual tentang bentuk pot bunga yng menyerupai lekukan dari lipatan kain keras yang disemen. Banyak poto ynag menunjukkan model pot bnga kekinian ini dengan berbagai variasi dan ukuran serta warna yang unik dan menarik. Beberapa pot bunga kekinian ini telah hadir lebih dahulu di daerah Bandung Jawa Barat dan sekitaarnya, lalu menyebar ke berbagai wilayah lainnya yang ada di Indonesia. Cara pembuatannya juga tergolong unik dan penuh kreatifitas, dengan memanfaatkan handuk yang di bentuk menyerupai lipatan dan kemudian disemen keras dengan bantuan kuas cat. Karena viral dipasarkan di media sosial dengan nama pot bunga kekinian, banyak masyrakat yang tertarik bahkan mencoba mengikuti cara pembuatannya serta menjadikannya usaha sampingan baru mereka. Namun ternyata menenukan kendala saat pembuatannya ternyata masih negalami kegagalan seperti mudah pecah atau retak, dan tidak keras dengan baik saat selesai dibuat.

Pengabdian yang mengarah kepada pendampingan entrepeanurship lebih bermanfaat dari pada penyuluhan biasa yang menjadi kegiatan PPM ke masyarakat mitra, terbukti dari keberanian mitra memulasi saha denga lebih yakin, (Kurniawan, 2021). Keahlian identifikasi peluang usaha bagi mitra akan memberikan dampak besar dibandingkan kegiatan seminar saja atau penyuluhan saja, karena akan menuntun kemana mitra berkarya dangan lebih focus dan menghasilkan (Ernawati, 2021). Sedangkan pemanfaatan digital marketing untuk komersialisasi produk yang di tawarkan juga menjadi solusi dalam pemasaran produk, dibandingkan cara lama yng menempatkan di kedai atau warung saja (Arifah, 2021). Setidaknya harus benar-benar memahami teknik pembuatan yang baik dan benar agara hasilnya layak untuk dijadikan produk bisnis yang menguntungkan keluarga.

\section{METODE}

Metode pelaksanaan pada Pengabdian Pada Masyarakat (PPM) adalah dengan mengadakan pelatihan dan workshop untuk memulai bisnis pembuatan pot bunga kekinian bagi warga Perumahan Baruna terutama warga masyarakat RT 07 yang rata-rata memiliki halaman rumah yang cukup tersedia. Metode yang digunakan dalam proses pelaksanaan pelatihan kewirausahaan ini adalah : 
1. Pembuatan modul pelatihan untuk motifasi memulai usaha

Sebelum pelatihan dilaksanakan terlebih dahulu tim dosen membuat modul yang akan digunakan dalam mengikuti proses pelatihan kewirausahaan untuk memulai bisnis. Modul berisikan informasi mengenai motifasi beriwausaha, ide produk dalam memulai usaha, dan teknik mewujudkan ide kewirausahaan dalam sebuah kegiatan yang nyata dan menghasilkan profit. Ini akan diukur dengan memberikan waktu untuk berdiskusi dan melakukan pertanyaan-pertanyaan dari materi modul yang diberikan ke peserta diklat.

2. Pelaksanaan Pelatihan pembuatan pot bunga kekinian

Pelatihan dilaksanakan di Perumahan Baruna Kelurahan Bukit Datuk. Materi pelatihan diberikan oleh tim dosen. Setelah materi tentang Kewirausahaan disampaikan dalam presentasi, diskusi dan tanya jawab selama kegiatan dilakukan. Selanjutnya diberikan pelatihan pembuatan pot bunga kekinian yang dituntun oleh pemateri dan instruktur yang berpengalaman membuat pot bunga . Setiap proses dijelaskan dan diurut agar di pahami oleh peserta, kemudian diberikan kesempatan untuk membuat masing-masing oleh setiap peserta agar dapat dinilai hasil pembuatannya.

Untuk mengukur tingkat ketercapaian keberhasilan kegiatan pengabdian, dilakukan dengan menilai kembali perubahan sikap peserta setelah mengikuti pelatihan apakah melakuakan kegiatan ini di rumahnya masing-masing, secara sosial apakah peserta berinteraksi untuk membahas hasil pembuatan potnya sudah baik dan layak untuk dijual, dan dinilai dari sisi ekonomi masyarakat sasaran sudahkan ada yang memiliki transaksi jual beli dari hasil pot kekinian buatannya.

\section{HASIL DAN PEMBAHASAN}

Kegiatan pengabdian ini telah dilaksanakan pada tanggal 17 Januari 2021 di RT 07 Kelurahan Bukit Datuk. Kegiatan ini diisi dengan materi mengenai pelatihan pembuatan pot bunga kekinian dan dilanjutkan tim STT Dumai tentang memulai wirausaha yang baik dan efektif. Jumlah peserta diikuti oleh 20 orang peserta. Para peserta sangat antusias untuk mengikuti kegiatan ini, dibuktikan dengan kedatangan mereka yang tepat waktu. Antusiasme juga terlihat dalam mendengarkan penjelasan dari pemateri dan banyaknya pertanyaan yang diajukan seputar materi yang diberikan. Walaupun diakhir sesi kegiatan disediakan waktu khusus untuk tanya jawab, namun beberapa peserta juga mengajukan pertanyaan disela-sela materi diberikan.

Materi diberikan dalam satu sesi presentasi dan ceramah dan diakhiri dengan sesi diskusi dan tanya jawab bersama Bapak Muhammad Arif, MT. Materi pertama adalah menjelaskan bagaimana ide dan perlunya motifasi untuk berwirausaha bagi para masyarakat perumahan Baruna baik kepada ibu rumah tangga dan pemuda maupun bapak -bapak yang tinggal di wilayah perumahan pegawai Distrik Navigasi Kota Dumai.

Materi kewirausahaan disampaikan oleh Tim STT Dumai yang telah dilaksanakan di depan peserta training kewirausahaan bina bisnis pot bunga kekinian, untuk memberikan pengertian dan tujuan serta kiat-kiat berwirausaha bagi para peserta. Sesi terakhir dilakukan tanya jawab seputar kegiatan memulai usaha, prospek usaha dan motifasi berbisnis pot bunga kekinian bagi masyarakat perumahan Baruna. Semoga dengan adanya materi kewirausahaan ini membantu pemahaman masyarakat untuk berani memulai usaha bisnis di rumahnya sendiri akan semakin banyak di masa mendatang. 
Sesi berikutnya adalah mempresentasikan teknik pembuatan pot kekinian yang di berikan kepada para peserta pelatihan, dan ditunjukkan tahap demi tahap, agar memudahkan untuk dikuti dan dilaksanakan di rumah masing-masing nantinya.

Adapun proses penjelasan tahapan pembuatan pot bunga kekinian tersebut yaitu, di mulai dari persiapan alat dan bahan yang dibutuhkan lalu dilanjutkan dengan proses kerja pembuatan potnya tahap demi tahap. Proses berikutnya adalah menyiapkan terlebih dahulu wadah keranjang kecil untuk mal bentuk pot bunga yang akan dibuat, tentunya sesuai ukuran yang akan direncanakan, kecil, sedang ataukah besar wadah sebagai mal bentuk potnya. Dilakukan pembentangan handuk yang sudah dibasahi dengan semen tadi ke posisi mal bentuknya dengan baik. Kemudian lakukan pembentukan gelombang permukaan handuk sesuai dengan arah dan model yang di kreasikan agar terlihat menarik dan indah. Tahap selanjutnya melakukan pelapisan semen ke handuk yang sudah di bentuk, dengan menggunakan kuas cat dan adonan semen yang sudah kita aduk rata sebelumnya. Dilakukan secara merata dengan di putar sekelilingnya, sehingga sama tebal dan kokoh hasilnya. Dari beberapa poto yang ada dapat digambarkan kegiatan selama penyuluhan yang berlangsung acara pelatihan bina bisnis pembuatan pot bunga kekinian yang telah berlangsung dengan sukses dan sesuai rencana pada tanggal 17 Januari 2021.

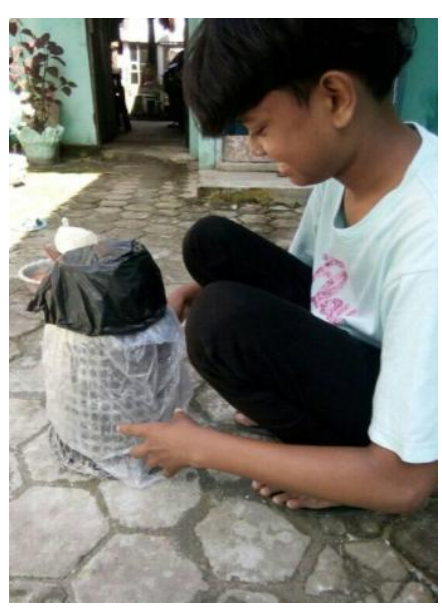

(a)

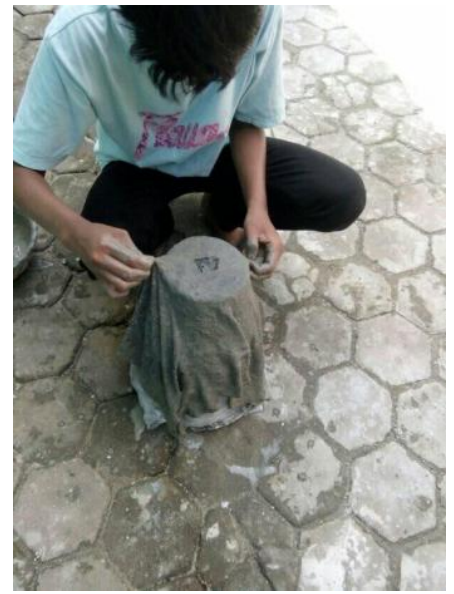

(b)

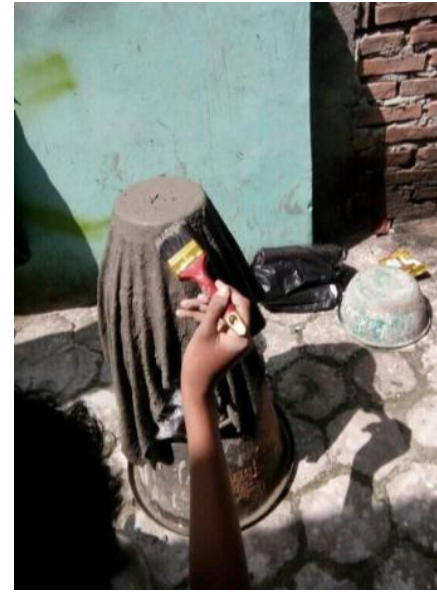

(c)

Gambar 1. Pembuatan Pot Kekinian (a) siapkan mal pot (b) pasang cetakan pot (c) penguasan pot

Langkah finishing atau terakhir adalah menjemur hasil pelapisan semen yang dilakukan dengan kuas tersebut sampai lumayan keras. Setelah keras kita lakukan penguasan dengan semen juga pada bagian dalam pot, lalu di jemur kembali sampe benar-benar keras, biasanya sampai 2 hari di bawah sinar matahari agar benar benar sempurna.

Setelah dilihat cukup rata pengerasan potnya barulah dilakukan langkah terakhir berupa pengecatan bentuk luar pot dengan warna yang diinginkan, dan semenarik mungkin bisa dikreasikan sesuai jiwa seni masing-masing pembuatnya. 


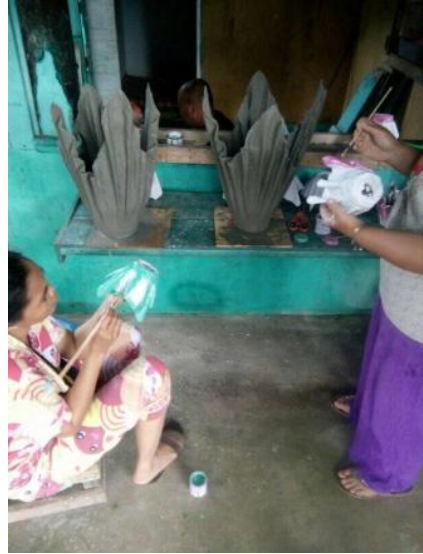

(a)

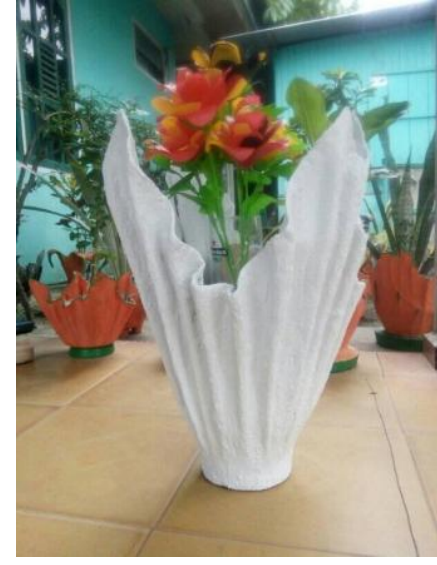

(b)

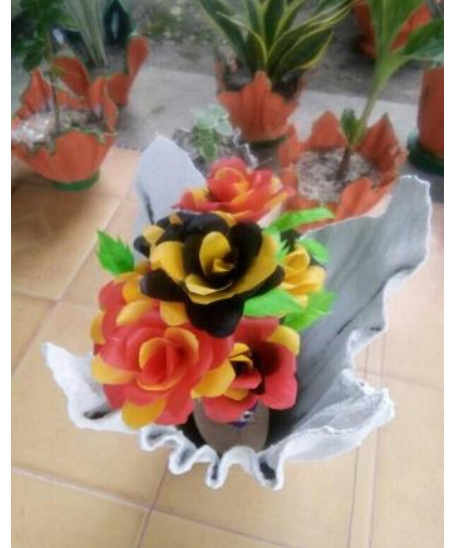

(c)

Gambar 2. Finishing (a) pengecatan (b) setelah dicat (c) pemakaian pot

Di sela-sela proses pembuatan pot bunga sampai ke sesi terakhir kegiatan pengabdian ini diselingi dengan adanya sesi tanya jawab. Peserta secara aktif mengajukan pertanyaan yang berkaitan dengan motifasi kewirausahaan, teknik berwirausaha bahkan terkait tentang cara kerja pembuatan pot bunganya. Beberapa pertanyaan yang diajukan misalnya kelebihan dan kelemahan menjalankan bisnis pot bunga kekinian, kendala dalam melakukan bisnis ini, dan bagaimana cara memulai semangat berwirausaha pot bunga kekinian agar lebih efektif dan efisien sebagai bisnis baru masyarakat di Perumahan Baruna Kelurahan Bukit Datuk.

Kegiatan tersebut telah mampu memberikan suatu nilai tambah bagi masyarakat perumahan Baruna, baik dalam kegiatan ekonomi keluarga kedepannya, dan perubahan perilaku dengan berani memulai sebuah kegiatan kewirausahaan di keluarga masing-masing peserta diklat. Setidaknya secara jangka pendek sudah tahu untuk memulai kegiatan kewirausahaan yang di berikan dalam kegiatan PPM ini, dan diharapkan pada jangka panjang juga menambah kemampuan pembuatan pot kekinian yang lebih bervariatif lagi bahkan kemampuan memulai jenis kewirausahaan yang baru dari apa yang telah di peroleh selama mengikuti diklat bina bisnis ini nantinya.

Sedangkan untuk merekap keaktifan dan luaran hasil diklat kewirausahaan pembuatan pot bunga kekiniaan ini dapat di gambarkan dari tabel rekap keaktifan peserta dikalat dibawah ini.

Tabel 1. Rekapitulasi Keaktifan dan Hasil Luaran Diklat Kewirausahaan

\begin{tabular}{cccc}
\hline $\begin{array}{c}\text { Jenis Kelamin } \\
\text { Peserta }\end{array}$ & $\begin{array}{c}\text { Mengikuti Diklat } \\
\text { Kewirausahaan }\end{array}$ & $\begin{array}{c}\text { Mengikuti Diklat } \\
\text { Pembuatan Pot }\end{array}$ & $\begin{array}{c}\text { Melaksanakan } \\
\text { Usaha Pembuatan } \\
\text { Pot di Rumahnya }\end{array}$ \\
\hline Pria & 12 & 12 & 8 \\
Wanita & 8 & 8 & 5 \\
Jumlah & 20 & 20 & 13 \\
\hline
\end{tabular}

Dari tabel rekapitulasi didapat persentase akhir luaran dari keaktifan peserta diklat yang benar-benar melakukan pembuatan pot bunga di rumahnya masing-masing adalah 13 orang dari keseluruhan peserta yang berjumlah 20 orang, ini menunjukkan keaktifan dibandingkan bentuk hasil luaran penerapan ilmu setelah kegiatan diklat mencapai 65 persen. Harapannya tentunya hasil diklat ini benar-benar berimplikasi 
positif untuk menawarkan bentuk kemampuan berwirausaha bagi semua peserta diklat, terlebih lagi dalam menghadapi keadaan kesulitan ekonomi dalam masa pendemi covid 19 yang masih dirasakan sampai saat ini. Sehingga bisa membantu pendapatan ekonomi keluaraga bagi yang melaksanakan hasil diklat ini dengan sunguh-sungguh.

\section{KESIMPULAN}

Dari hasil kegiatan pelatihan kewirausahaan bina bisnis pembuatan pot bunga kekinian yang telah dilakukan ini ditarik beberapa kesimpulan sebagai berikut :

1. Kegiatan ini mampu berperan serta dalam membangun jiwa berwirausaha dan menjadi peluang bisnis keluarga walaupun dalam skala kecil sembari menyalurkan hobi menanam bunga yang dimiliki ibu-ibu di era pendemi Covid 19 saat ini, dan juga sumber pendapat tambahan bagi ekonomi keluarga.

2. Mitra PPM dapat merancang bisnis baru mereka, proses dan tahapan pembuatan pot bunga kekinian sehingga lebih berguna dibandingkan dengan beberapa bisnis yang pernah ditawarkan kepada mereka sebelumnya atau yang sama sekali belum pernah mendapatkannya.

3. Kedepannya, diperlukan suatu pelatihan yang lebih mendalam untuk meningkatkan peran aktif masyarakat dalam ikut mengatasi masalah-masalah yang muncul dalam memulai dunia usaha. Pelatihan yang dapat diselenggarakan misalnya pelatihan tentang produk baru yang lagi booming, produk inovatif, bahkan pengelolaan alat-alat bantu kerja yang lainnya sesuai dengan kebutuhan dan bidang usaha yang dijalankan oleh masyarakat. Sehingga akan semakin memaksimalkan pengelolaan suatu usaha dan dapat bersaing dalam menghadapi tekanan ekonomi semasa era pendemi covid 19 saat ini.

\section{UCAPAN TERIMA KASIH}

Penulis mengucapkan terima kasih kepada Bapak M. Syahnir sebagai Ketua RT 007 di Perumahan Baruna yang telah memberi dukungan terhadap terlaksananya kegiatan pengabdian ini. Juga Bapak Parizal atas kesediaannya jadi instruktur bagi pelatihan pembuatan pot bunga kekiniaan yang sudah duluan memulai bisnis ini.

\section{DAFTAR PUSTAKA}

Aqmala, Diana. (2021). Pemanfaatan E-Comerce Sebagai Media Start Up Bisnis Pada Anak-Anak Panti Asuhan Riyadul Jannah. Abdimasku, 4(1), 55-63.

Arifah, Rani, Normawati, (2021). Pemanfaatan Digital Marketing sebagai sarana Komersialisasi Produk Kampung Batik Kembang Turi Blitar, Dinamisia,5(1), 253261

Arif, Muhammad. (2016). Rancangan Teknik Industri, Deepublish, Yogyakarta.

Ernawati. (2021). Peningkatan Keahlian Identifikasi Peluang Usaha Bagi Calon Wirausaha di Kota Kendari, Dinamisia,5(1), 89-96

Gamayanto, Indra. (2021). Pelatihan dan Implementasi Social Media Profilling Untuk Meningkatkan Kompetensi Pada SMA Negeri 3 Semarang, Abdimasku, 4(1), 26-35

Ginting R. (2014) Perancangan Produk, Graha Ilmu, Yogyakarta.

Kurniawan,Andri. (2021). Pendampingan Entrepeaneurship Budidaya Dan Pemasaran Ikan Cupang, Abdimasku, 2(1), 14-19

Nurmianto, Eko. (2014). E-Comerce dan Aplikasinya, Penerbit Guna Widya, Surabaya Purnomo, Hari. (2012) Media Social Untuk Promosi, Graha Ilmu, Yogyakarta 